\title{
REDUPLIKASI BAHASA MELAYU RIAU DIALEK KAMPAR KIRI
}

\author{
Mella Andriana ${ }^{1,}$ Auzar $^{2,}$ Charlina $^{3}$ \\ Universitas Riau, Pekanbaru, Indonesia ${ }^{1,2,3}$ \\ mellaandriana87@gmail.com ${ }^{1}$, auzarthaher54@gmail.com ${ }^{2}$, charlina@lecturer.unri.ac.id ${ }^{3}$
}

\begin{abstract}
This study aimed to analyze the form and meaning of reduplication in the Malay language of the Kampar Kiri dialect. This study used a qualitative approach and descriptive method which aimed to describe the form of reduplication and analyze the meaning of the Malay language of Kampar Kiri dialect. The object of this study was in the form of Riau Malay dialect Kampar Kiri dialect used by the people of Batu Sasak Village. Data was obtained by fishing techniques, interview techniques, record techniques, and note-taking techniques. The data were described based on the type and analyzed based on the meaning of the reduplication of the Malay language in the Kampar Kiri dialect. Data that has been analyzed are then formulated into conclusions. After analyzing the data, ten forms were found, namely one beinfix reduplication, three sulfimated reduplication, six prefixed reduplication in the first phallus, four had reduplication prefixed on the second phallus, and three were suffixed reduplication. In addition, six confixed reduplication, five regional reduplication, three voice copy reduplication, ten affixed duplication reduplication, and ten duplicate reduplication without affixes. The total number of forms of reduplication in Riau Malay in the Kampaar Kiri dialect were 51 one data.
\end{abstract}

Keywords: reduplication, Riau Malay, Kampar Kiri dialect

\begin{abstract}
ABSTRAK
Penelitian ini bertujuan untuk menganalisis bentuk dan makna reduplikasi pada bahasa Melayu Riau dialek Kampar Kiri. Penelitian ini menggunakan pendekatan kualitatif dan medote deskriptif yang bertujuan untuk mendeskrpsikan bentuk reduplikasi dalam bahasa Melayu Riau dialek Kampar Kiri dan menganalisis makna bahasa Melayu Riau dialek Kampar Kiri. Objek penelitian ini berupa ujaran bahasa Melayu Riau dialek Kampar Kiri yang digunakan oleh masyarakat Desa Batu Sasak. Data diperoleh dengan teknik pancing, teknik wawancara, teknik rekam, dan teknik pencatatan. Data dideskripsikan berdasarkan bentuk dan dianalisis berdasarkan makna reduplikasi bahasa Melayu Riau dialek Kampar Kiri. Data yang sudah dianalisis kemudian dirumuskan menjadi simpulan. Dari data yang dianalisis ditemukan sepuluh bentuk, yaitu satu reduplikasi beinfiks, tiga reduplikasi bersimulfiks, enam reduplikasi berprefiks pada lingga pertama, empat reduplikasi berprefiks pada lingga kedua, dan tiga reduplikasi bersufiks. Selain itu, enam reduplikasi berkonfiks, lima reduplikasi dwilingga, tiga reduplikasi dwilingga salin suara, sepuluh reduplikasi dwipura berafiks, dan sepuluh reduplikasi dwipura tanpa afiks. Jumlah keseluruhan bentuk reduplikasi bahasa Melayu Riau dialek Kampaar Kiri sebanyak 51 satu data.
\end{abstract}

Kata Kunci: bahasa Melayu Riau, dialek Kampar Kiri, reduplikasi

\section{PENDAHULUAN}

Manusia adalah makhluk sosial yang tidak dapat hidup sendiri, dengan kata lain manusia membutuhkan individu lainnya dalam kelangsungan hidup. Oleh karena manusia perlu bahasa untuk alat komunikasi atau berinteraksi dengan sesamanya dalam melangsungkan hidupnya sebagai makhluk sosial. Di samping itu, dengan bahasa manusia akan mudah bergaul dan bersosialisasi dengan sesama mereka.

Bahasa merupakan komponen terpenting dalam kelanjuan hidup manusia. Melalui bahasa, setiap orang dapat

Reduplikasi Bahasa Melayu Riau Dialek Kampar Kiri 
menyampaikan maksud yang dipikirkannya kepada orang lain. Bahasa disampaikan baik melalui lisan maupun bentuk tulisan. Bahasa dan masyarakat tidak bisa dilepas karena bahasa dengan masyarakat memiliki kaitan erat, masyarakat tidak mungkin bisa berkomunikasi tanpa bahasa begitu juga sebaliknya bahasa tidak akan ada jika tidak ada masyarakat. Oleh karena itu, bahasa memiliki peranan yang penting dalam kehidupan bermasyarakat untuk berkomunikasi (Alber dan Febria, 2018:78; Nalenan, 2019:103-104; dan Kurniawam, 2015:161).

Bahasa Indonesia memiliki bahasa kesatuan atau bahasa nasional yang digunakan oleh warga negara Indonesia untuk berkomunikasi. Hal tersebut ditandai dengan lahirnya sumpah pemuda pada tanggal 18 Oktober 1928. Bahasa yang ada dalam masyarakat akhirnya menjadi kebiasaan yang diwariskan secara turun-temurun sehingga bahasa Indonesia menjadi sebuah budaya atau ciri khas warga negara Indonesia.

Selain memiliki bahasa kenegaraan, Indonesia juga memiliki berbagai bahasa daerah dan suku budaya yang terdapat dalam suatu daerah. Indonesia memiliki lebih dari 746 bahasa daerah dan 17.508 pulau. Kebanyakan bahasa daerah terutama yangg kecil-kecil komunitasnya serta turun temurun dipakai secara lisan akibatnya setelah penutur aslinya tidak ada bahasa tersebut akan hilang. (Sumber:bahasakita.com, 25 Februari 2019).

Auzar dan Hermandra (2007:12) mengatakan bahwa dialek suatu bahasa dapat kita jumpai hampir pada semua daerah yang ada di Indonesia, seperti daerah yang terdapat di Riau. Bahasa Melayu misalnya memiliki beberapa dialek yang berbeda-beda, bahasa yang sering digunakan seperti bahasa Melayu dialek Kepulauan, bahasa Melayu dialek bengkalis, dan yang lainnya. Setiap bahasa tersebut terdapat reduplikasi di dalam berkomunikasi.

Reduplikasi atau proses pengulangan merupakan proses pengulangan bentuk, baik seluruh maupun sebagian, baik dengan variasi fonem maupun tidak (Ramlan, 2001:63; Oktavia, 2018:81; dan Asnawi, 2017:34). Hasil pengulangan disebut kata ulang, sedangkan bentuk yang diulang merupakan bentuk dasar. Kata ulang rumah-rumah dari kata dasar rumah. Dari pendapat Ramlan dapat diambil simpulan bahwa reduplikasi dapat terbentuk dari berbagai proses, baik proses pengulangan seluruh, contoh: mobil-mobil. Pengulangan sebagian, contoh: membukabuka. Pengulangan yang berkombinasi dengan pembubuhan afiks, contoh: goda-menggoda.

Sejalan dengan pendapat di atas, Muslich (2010:48) mengatakan bahwa proses reduplikasi merupakan peristiwa pembentukan kata dengan jalan mengulang bentuk dasar, baik seluruhnya maupun sebagian, baik bervariasi fonem maupun tidak, baik berkombinasi dengan afiks maupun tidak. Berdasarkan pendapat Muslich dapat disimpulkan bahwa reduplikasi mempunyai empat bentuk, yaitu pengulangan seluruh, contoh: batu-batu. Pengulangan sebagian, contoh: menulis-nulis. Pengulangan yang berkombinasi dengan pembubuhan afiks, contoh: kuda-kudaan. Pengulangan dengan perubahan fonem, contoh: gerak-gerik.

Charlina dan Sinaga (2007:37) juga berpendapat bahwa reduplikasi merupakan pengulangan suatu gramatik, baik seluruh maupun sebagian, baik berkombinasi dengan afiks maupun tidak, baik dengan variasi fonem maupun tidak. Hasil pengulangan itu disebut dengan kata ulang, sedangkan suatu yang diulang merupakan bentuk dasar, misalnya kata ulang meja-meja dari bentuk dasar meja, bermain-main dari bentuk dasar main, pukulmemukul dari bentuk dasar memukul. Berdasarkan pendapat tersebut, penulis menyimpulkan bahwa reduplikasi menurut Charlina dan Sinaga sejalan dengan reduplikasi menurut Ramlan karena mempunyai proses yang sama, yaitu proses pengulangan seluruh, pengulangan sebagian, dan pengulangan yang berkombinasi dengan pembubuhan afiks.

Keraf (1989:120) mengatakan bahwa dalam semua tatabahasa tradisiaonal, kata-kata ulang disebut juga reduplikasi. Istilah ini sering digunakan dalam bahasa-bahasa Barat, dimana ulangan itu terjadi dengan menggandakan suku kata awal. Berdasarkan pendapat Keraf dapat disimpulkan bahwa reduplikasi merupakan pengulangan yang mengulang suku awal dan digunakan dalam

Reduplikasi Bahasa Melayu Riau Dialek Kampar Kiri 
tata bahasa pertama berdasarkan bentuk pengulangannya.

Menurut Kridalaksana (2008:143)

reduplikasi sebagai proses dan hasil pengulangan suatu bahasa sebagai alat fonologi gramatikal. Jadi, dalam proses redupikasi ada pengulangan bentuk dasar yang bisa dikombinasikan dengan unsur lain. Dari pendapat Kridalaksana dapat disimpulkan bahwa reduplikasi memiliki lima bentuk reduplikasi yaitu reduplikasi dwipura, reduplikasi dwilingga, reduplikasi dwilingga salin suara, reduplikasi dwiwasana, dan reduplikasi trilingga.

Berdasarkan pendapat Ramlan, Muslich, Charlina dan Sinaga, Keraf, dan penulis menyimpulkan reduplikasi adalah sebuah ujaran ynag mengalami proses pengulangan, baik keseluruhan maupun sebagian, terjadi perubahan fonem maupun tidak. Reduplikasi merupakan bentuk yang unik. Hal ini disebabkan oleh perbedaan sudut pandang dan klarifikasi pada teori bahasa. Meskipun bentuknya kelompok kata, tetap masih dikelompokkan menjadi sebuak kata bukan frasa. Melihat keunikan reduplikasi tersebut, penulis tertarik untuk membahas tentang reduplikasi dalam penelitian ini. Penelitian ini akan difokuskan pada bentuk dan makna redulikasi yang terdapat pada bahasa Melayu Riau dialek Kampar Kiri.

Di Provinsi Riau terdapat sebuah kecamatan di Kabupaten Kampar yaitu Kecamatan Kampar Kiri. Mayoritas penduduk Kampar Kiri bersuku Melayu. Oleh karena itu, bahasa daerah yang digunakan dalam kehidupan sehari-hari adalah bahasa Melayu Riau dialek Kampar Kiri. Melihat perkembangan teknologi saat ini, Kecamatan Kampar Kiri secara berangsur-angsur mengalami perubahan terhadap berbagai nilai kehidupan masyarakat seperti adat-istiadat, pendidikan, dan perekonomian. Perubahan tersebut menimbulkan pergeseran terhadap cara berperilaku, berpikir serta berbahasa itu sendiri, terlebih lagi dengan datangnya berbagai pendatang dari berbagai daerah seperti Minang dan Jawa yang mempunyai bahasa yang berbeda.
Reduplikasi bahasa Melayu Riau dialek Kampar Kiri sering digunakan oleh masyarakat dalam percakapan, hal ini dikarenakan adanya satuan-satuan kata tertentu yang memang sudah terbentuk dan ditentukan, reduplikasi yang terdapat pada percakapan masyarakat Kampar Kiri hampir sama dengan reduplikasi yang ada pada percakapan bahasa Indonesia, hanya saja ada fonem-fonem tertentu yang membedakan tulisan dan pengucapannya.

Masyarakat adat Kampar Kiri secara kebudayaaan menganut kebudayaan matrilineal yaitu garis kekerabatan ditarik dari pihak ibu. Kebudayan ini dikenal dengan budaya Minangkabau, sedangkan sistem perkawinannya adalah sistem matrilokal di mana seseorang harus mencari pasangan di luar sukunya. Secara adat-istiadat penduduk Kampar Kiri terdiri dari beberapa suku atau pesukuan yaitu terdiri dari suku Pitopang Basa dengan kepala suku Datuk Jalelo, suku Piliang dengan kepala suku Datuk Mongguong atau Tumenggung, suku Domo dengan kepala suku Datuk Paduko Tuan, suku Melayu Datuk Marajo dengan kepala suku Datuk Majo. Khalifah Kampar Kiri bergelar Datuk Besar yaitu H. Raylus Bin H Nurdin.

Bahasa Melayu di Kecamatan Kampar Kiri dilihat dalam konteks fenomena bahasa, para orang tualah yang mengambil peran dalam melestarikan fenomena bahasa tersebut hal yang berbeda jika ditinjau dari sisi generasi mudanya, sehingga terjadi ketakutan akan punahnya bahasa Melayu di Kecamatan Kampar Kiri. Maka dari itu, peneliti ingin membantu proses pendokumentasian berhasa tersebut ke dalam penelitian. Itulah yang menyebabkan peneliti ingin mengangkat bahasa Melayu dialek Kampar Kiri Kabupaten Kampar sebagai objek penelitian. Selain itu, peneliti sendiri di besarkan di desa Batu Sasak Kabupaten Kampar. Penelitian ini diharapkan akan bisa menjadi acuan atau pedoman untuk masyarakat atau generasi muda yang akan datang untuk tidak melupakan dan tetap melestarikan bahasa daerah yang dimiliki oleh masyarakat Kampar Kiri.

Terjadinya perubahan tersebut, berpengaruh terhadap kepunahan bahasa yang Reduplikasi Bahasa Melayu Riau Dialek Kampar Kiri 
dimiliki oleh masyarakat Kampar Kiri yang sedikit demi sedikit akan menghilang. Terjadinya kepunahan bahasa tersebut, diakibatkan oleh masyarakat yang sering menggunakan istilah atau bahasa asing lainnya untuk berkomunikasi dalam kehidupan seharihari. Maka dari itu penulis ingin meneliti mengenai reduplikasi bahasa Melayu Riau dialek Kamapar Kiri.

\section{METODOLOGI PENELITIAN}

Penelitian ini dilaksanakan mulai bulan Juni sampai dengan Desember 2019, metode yang digunakan dalam penelitian ini adalah metode kualitatif. Menurut Moleong (2005:5) penelitian kualitatif adalah penelitian yang bermaksud untuk memehami fenomena tentang apa yang dialami oleh subjek penelitian Sumber data penelitian ini adalah bahasa lisan yang diambil dari bahasa seharihari masyarakat Kampar Kiri, Kabupaten Kampar. Bentuk dan makna reduplikasi dalam penelitian adalah bentuk dan makna reduplikasi dari pendapat Keraf.

Menurut Keraf bentuk reduplikasi terbagi menjadi sepuluh bentuk, yaitu reduplikasi beinfiks, reduplikasi bersimulfiks, reduplikasi berprefiks pada lingga pertama, reduplikasi berprefiks pada lingga kedua, dan reduplikasi bersufiks. Selain itu, reduplikasi berkonfiks, reduplikasi dwilingga, reduplikasi dwilingga salin suara, reduplikasi dwipura berafiks, dan reduplikasi dwipura tanpa afiks, sedangkan makna reduplikasi hanya terbagi menjadi tujuh makna, yaitu makna jamak, makna bermacam-macam, makna menyerupai atau seperti, makna sampai atau pernah, makna superlatif, makna saling berbalasan, dan makna kolektif. Namun penulis menemukan sepuluh makna reduplikasi pada penelitian ini.

\section{HASIL DAN PEMBAHASAN}

Bentuk-bentuk Reduplikasi Bahasa Melayu Riau Dialek Kampar Kiri

Bentuk-bentuk reduplikasi merupakan bagian dari reduplikasi itu sendiri. bentukbentuk reduplikasi bahasa Melayu Riau dialek Kampar Kiri teori Keraf yang meliputi reduplikasi berafiks, reduplikasi beinfiks, reduplikasi bersimulfiks, reduplikasi berprefiks pada lingga pertama, reduplikasi berprefiks pada lingga kedua, reduplikasi bersufiks, reduplikasi berkonfiks, reduplikasi dwilingga, reduplikasi dwilingga salin suara, reduplikasi dwipura berafiks, dan reduplikasi dwipura tanpa afiks.

Berdasarkan penelitian bentuk reduplikasi bahasa Melayu Riau dialek Kampar Kiri hanya terdapat 1 reduplikasi beinfiks, 3 reduplikasi bersimulfiks, 6 reduplikasi berprefiks pada lingga pertama, 4 reduplikasi berprefiks pada lingga kedua, dan 3 reduplikasi bersufiks. Selain itu, 6 reduplikasi berkonfiks, 5 reduplikasi dwilingga, 3 reduplikasi dwilingga salin suara, 10 reduplikasi dwipura berafiks, dan 10 reduplikasi dwipura tanpa afiks. Untuk lebih jelasnya dapat dilihat pada di bawah ini.

\section{Reduplikasi Berafiks}

Reduplikasi berafiks merupakan pengulangan yang mendapat imbuhan pada lingga pertama dan pada lingga kedua. Pada penelitian ini berdasarkan data yang telah didapatkan setelah melakukan penelitian di Kecamatan Kampar Kiri Kabupaten Kampar, reduplikasi berafiks menjadi beberapa macam, diantaranya reduplikasi dengan infiks, reduplikasi dengan simulfiks, reduplikasi dengan prefiks, reduplikasi sufiks, dan reduplikasi konfiks. Berikut penulis sajikan contoh bentuk reduplikasi berafiks yang terdapat pada dialek Kampar Kecamatan Kampar Kiri.

\section{Reduplikasi Berinfiks}

Reduplikasi berinfiks yaitu pengulangan yang mendapat imbuhan di tengah atau merupakan penambahan afiks bentuk sisispan di tengah bentuk dasar. Jadi, infiks adalah proses penambahan infiks di tengah bentuk dasar. Contoh data tali yang mendapat penambahan $\{\mathrm{ta} \rightarrow$ te $\}$ setelah kata dasar sehingga menjadi tamali.

\section{Reduplikasi Bersimulfiks}

Pada data (1) terdapat kata dasar campak yang mendapat pengulangan yang terjadi ataupun yang mendapat imbuhan di awal dan di akhir kata baik pada lingga pertama maupun pada lingga kedua, data (1) mendapat imbuhan $\{\mathrm{di}\}$ di awal, dan mendapat akhiran \{an\}sehingga kata campak akhirnya 
mendapat reduplikasi menjadi dicampak-

campaan. Begitu pula pada data (2) dan (3) mendapat imbugan di awal dan diakhir katanya baik pada lingga pertama maupun lingga ke dua.

Kata dasar campak mempunyai arti buang, sehingga reduplikasinya menjadi dicampak-campaan artinya unsur kesengajaan yang dilakukan untuk membuang sesuatu. Kata dasar omak mempunyai arti seorang ibu, sedangkan reduplikasi kaomak-omakan mempunyai arti sifat keibuan. Kata dasar pajagh mempunyai arti anak, sedangkan reduplikasi kapajagh-pajaghan mempunyai arti sifat seperti anak-anak.

\section{Reduplikasi Berprefiks}

Reduplikasi berprefiks merupakan pengulangan yang terdapat imbuhan di awal kata. Berdasarkan penelitian yang dilakukan di Kecamatan Kampar Kiri, Kabupaten Kampar, Reduplikasi prefiks ini terbagi atas dua di antaranya reduplikasi prefiks pada lingga pertama dan reduplikasi pada prefiks lingga kedua, yaitu:

\section{Reduplikasi Berprefiks pada Lingga Pertama}

Pada data (1) di atas terdapat kata dasar butigh yaitu pengulangan yang mendapat imbuhan di awal kata pada lingga tersebut, mendapatkan imbuhan $\{\mathrm{sa} \rightarrow \mathrm{se}\}$, sehingga menjadi sabutigh. Data (2) mangkuak yang mendapat imbuhan $\quad\{\mathrm{sa} \rightarrow$ se $\}$, sehingga menjadi samangkuak dan data (3) kata dasar yang mendapat imbuhan $\{\mathrm{ma} \rightarrow \mathrm{me}\}$ tengok dan akhirnya menjadi manengok. Begitupula pada data (4) (5) dan (6) kata dasar yang mendapat imbuhan $\{\mathrm{sa} \rightarrow \mathrm{se}, \mathrm{ta} \rightarrow t e, b a \rightarrow b e\}$ kobek, hompe,golak dan akhirnya menjadi sakobek, tahompe, dan bagolak.

\section{Reduplikasi Berprefiks pada Lingga Kedua}

Pada data (1), (2), dan (3) terdapat kata dasar tampagh, piciak, pogang, mendapatkan imbuhan $\{\mathrm{ma} \rightarrow \mathrm{me}\}$ sehingga menjadi manampagh, mamiciak, dan mamogang. Pada data (4) dengan kata dasar jopuik, mendapat imbuhan $\{\mathrm{man} \rightarrow \mathrm{men}\}$ sehingga menjadi manjopuik.
Kata dasar tampagh mempunyai arti pukulan dengan menggunakan telapak tangan, sedangkan reduplikasinya tampaghmanampagh memukul sesuatu dengan menggunakan telapak tangan yang dilakukan berulang kali. Reduplikasi piciak-mamiciak mempunyai arti menjepit dengan ibu jari dan telunjuk atau jari lainnya. Sama halnya dengan kata lainnya mempunyai arti berulang kali dilakukan.

\section{Reduplikasi Bersufiks}

Pada data (1) di atas, terdapat kata dasar mabuak yang mendapat imbuhan di akhir kata pada lingga kedua dan mendapat imbuhan $\{$ an $\}$ sehingga menjadi mabuan. Pada data (2) dan (3) terdapat kata dasar tengok dan salam yang sama-sama mendapat imbuhan \{an\}, sehingga menjadi tengokan dan salaman.

Reduplikasi mabuak-mabuan berbuat di luar kesadaran atau hilang kesadaran yang dilakukan berkali-kali. Reduplikasi tengoktengoan mempunyai arti saling melihat. Reduplikasi salam-salaman artinya saling berjabat tangan. Reduplikasi lambek-lambean memanjangkan waktu.

\section{Reduplikasi Berkonfiks}

Kata dasar pada data (1) ancak yang mendapat imbuhan di awal $\{\mathrm{sa} \rightarrow \mathrm{se}\}$, dan akhiran $\{\mathrm{e} \rightarrow n y a\}$, sehingga reuplikasinya menjadi saancak-ancak e. Pada data (2) kata dasar gendut dengan imbuhan di awal $\{\mathrm{sa} \rightarrow \mathrm{se}\}, \quad$ dan $\quad$ akhiran $\quad\{\mathrm{e} \rightarrow$ nya $\}$, reduplikasinya sagendut-gendut e. Begitupula pada data (3), (4), (5) dan (6) dengan kata dasar kuwi, pendek, elok dan kayo, sehingga reduplikasinya sakuwi-kuwi e, sapendekpendek e, saelok-elok e, dan sakayo-kayo e.

\section{Reduplikasi Dwilingga}

Berdasrkan di atas, pada data (1) dengan kata dasar tigo yang mendapat pengulangan seluruh bagian bentuk sehingga reduplikasi menjadi tigo-tigo. Pada data (2) dan (3) dengan bentuk dasar lambek, sehingga mendapat reduplikasi, lambek-lambek, laghilaghi. Begitupula pada data (4) dan (5) dengan kata dasar duduak, $\log u$ mendapat pengulangan seluruh bagian dari bentuk

Reduplikasi Bahasa Melayu Riau Dialek Kampar Kiri 
dasarnya sehingga menjadi duduak-duduak, dan $\log u-\log u$.

\section{Reduplikasi Dwilingga Salin Suara}

Pada data (1) di atas dengan kata dasar kata dasar mondagh sehingga mendapat reduplikasi menjadi mondagh-mandigh. Pada data (2) yang merupakan kata dasar sayugh, mendapat perubahan fonem menjadi mayugh sehingga kata dasar tersebut menjadi sayughmayugh. Sama halnya dengan data (3), kata dasar goghak yang mendapat perubahan fonem menjadi goghik sehingga reduplikasinya goghak-gaghik.

\section{Reduplikasi Dwipura}

Reduplikasi dwipura adalah reduplikasi dengan pengulangan vokal atau pengulangan bunyidari suku kata awalnya. Reduplikasi dwipura terbagi menjadi dua, yaitu reduplikasi dwipura berafiks dan reduplikasi dwipura tanpa afiks.

\section{Reduplikasi Dwipura Berafiks}

Pada data (1), (2), (3), (4), dan (5) terjadi pengulangan suku kata yang diserta dengan afiks, laghi, jalan, malam, aghi, dan jomugh merupakan kata dasar yang pada akhirnya menjadi balaghi, bajalan, bamalam, baaghi, dan bajomugh adanya penambahan afiks $\{\mathrm{ba} \rightarrow$ ber $\}$ dan mendapat reduplikasi balaghi-laghi, bajalan-jalan, bamalammalam, baaghi-aghi, dan bajomugh-jomugh. Begitupula pada data (6), (7), (8), dan (9) dengan kata dasar ingek, lompek, kunyah, nuli dan cukigh mendapatkan pengulangan dengan suku kata yang disertai afiks $\{\mathrm{ma} \rightarrow \mathrm{me}\}$ sehingga menjadi maingek, malompek, mangunyah, manuli dan mancukigh sehingga mendapat reduplikasi menjadi maingek-ingek, malompek-lompek, mangunyah-ngunyah, manuli-nuli dan mancukigh. Makna reduplikasi di atas yaitu berulang kali dilakukan.

\section{Reduplikasi Dwipura Tanpa Afiks}

Pada data (1), (2), (3), (4), dan (5) kata dasar oti, tarompa, adiak, aghi, dan padusi pengulangan suku awal yang tidak diserta afiks sehingga menjadi oti-oti, tarompatarompa, adiak-adiak,aghi-aghi, dan padusi- padusi. Begitupula pada data (6), (7), (8), (9) dan (10) kata dasar bantagh, obuak, piti, ughang, dan lukoyang merupakan kata dasar pengulangan suku kata awal yang tidak mendapatkan afiks sehingga menjadi bantaghbantagh, obuak-obuak,piti-piti, ughangughang dan luko-luko.

\section{Makna Reduplikasi Bahasa Melayu Riau Dialek Kampar Kiri}

Pada penelitian ini, dari segi makna reduplikasi bahasa Melayu Riau dialek Kampar Kiri maka didapatkan 10 macam makna reduplikasi, yaitu 3 makna bermacammacam, 2 menyatakan arti menyerupai atau seperti, 10 arti jamak, 11 menyatakan bahwa pekerjaan yang dilakukan berkali-kali atau berulang-ulang, 7 menyatakan bahwa pekerjaan yang disebutkan dalam kata dasarnya sedang berlangsung atau terusmenerus, 6 makna berbalasan, 2 makna sampai atau pernah, 6 makna superlatif, 3 makna demi, dan 1 makna kolektif. Jumlah keseluruhan data mengenai makna reduplikasi yang terdapat pada Dialek Kecamatan Kampar Kiri Kabupaten Kampar berjumlah 51 data.

\section{Menytakan Arti Bermacam-macam}

1. ' $\log u$ - $\log u$ Indonesia ko banyak macamnyo, ado logu dangdut, pop, rock, jo mandarin tu banyak lai yang lain, lupo den,.

2. 'Pasagh Senin potang, boli sayughmayugh den, ado sayugh kangkuang, bayam, pucuak ngalo, jo japan'.

3. 'Ayah tu tako banyak boli tali-tamalinyo, ado tali mambo, tali nilun, tu tali tarik tambang, ontah untuak apo e gak.

Pada reduplikasi $\log u-\log u$ ' $\log u-\log u$ Indonesia ko banyak macamnyo, ado logu dangdut, pop, rock, jo mandarin tu banyak lai yang lain, lupo den, merupakan bnayaknya jenis lagu yang ada di Indonesia. Pada redulikasi sayugh-mayugh dengan kalimat 'Pasagh Senin potang, boli sayugh-mayugh den, ado sayugh kangkuang, bayam, pucuak ngalo, jo japan', menjelaskan bahwa banyaknya macam sayuran yang dibeli oleh seorang saat belanja ke pasar. Reduplikasi tali-

Reduplikasi Bahasa Melayu Riau Dialek Kampar Kiri 
tamali dalam kalimat menjelaskan bahwa 'Ayah tu tako banyak boli tali-tamalinyo, ado tali mambo, tali nilun, tu tali tarik tambang, ontah untuak apo e gak.

\section{Makna Menyerupai atau Seperti}

1. Anak ughang dokek lapang poli tu olah baumugh, tapi pongainyo masih jondo kapajagh-pajaghan.

2. Waktu di pasagh tako nampak dek den pajagh gadih tu jo adiaknyo de balanjo, yo kaomak-omakan kali nampak den.

Pada reduplikasi dengan kalimat 'Anak ughang dokek lapang poli tu olah baumugh, tapi pongainyo masih jondo kapajagh-pajaghan', menjelaskan bahwa seseorang yang sudah berumur tetapi masih sifat atau perilakunya masih seperti anak-anak. Reduplikasi dalam kalimat 'Waktu di pasagh tako nampak dek den pajagh gadih tu jo adiaknyo de balanjo, yo kaomak-omakan kali nampak den', menjelaskan bahwa ada seorang gadis yang sifatnya seperti keibu-ibuan.

\section{Menyatakan Arti Banyak (jamak)}

1. Oti-oti yang di jogh di kodai dopan tu olah batinawan, banyak pulo taboli dek den tako.

2. Poi mayang den tako ka masojik, pas kulogh nondak baliak ilang sodo tarompatarompa ughang yang mayang masojik de.

3. Inyo bacakap saketek kasagh ndak sadar nyo da banyak adiak-adiak e situ.

4. Anak den olah baaghi-aghi poi ka Pokanbaghu olun jua baliak nyo lai.

5. Padusi-padusi kampuang siko banyak jua yang sekolah ka pokanbaghu.

6. Nampak den tako yo banyak bantaghbantagh jomugh e dek ughang tu dopan umah e.

7. Umah ughang tu jaghang mungkin disapu e, obuak-obuak nyia di lantai de.

8. Piti-piti den yang ado di ATM tu ntah bekpon cagho ambiak lai de, lupo den PIN nyo de.

9. Ughang-ughang di pasagh tu campakan saghok sembarangan ajo nyia ndak padulinyo da kabarisian.

10.Ughang yang poi caghi ikan tako olah luko-luko badan e gabiak dek bibe.
'Oti-oti yang dijogh di kodai dopan tu olah batinawan, banyak pulo taboli dek den tako. Poi mayang den tako ka masojik, pas kulogh nondak baliak ilang sodo tarompatarompa ughang yang mayang masojik de. Data tersebut sama-sama menjelaskan arti banyak atau jamak.

\section{Reduplikasi Makna Berkali-kali atau Berulang-ulang}

1. Dai tadi nampak den lai pajagh tu balghilaghi jua kojo, idak ponek ngko da yo.

2. Lupo den namo pajagh tu, lah lamo den cubo maingek-ingek indak juo taingek den do.

3. Anak den konciang nyo tadi malam di kasugh taga dek malompek-lompek juo kojo siang aghi.

4. Sakik kaki den dek bajalan-jalan towi, olah dua aghi ko den jalan ka ladang.

5. Yo tia bongi ati den nengok pajagh tu, lo bajomugh-jomugh jua kojo ndak tontu e da aghi paneh.

6. Apo tia yang dimakan dek pajagh tu de, ndak bonti nyo mangunyah-ngunyah nampak den dai tako.

7. Olah usak pulo pintu umah den, nyo ilang dek anak den kunci umah tako, lah den cubo mancukigh-cukigh jo obeng ndak jua bisa da.

8. Bongi abah anak den samo inyo tako, manuli-nuli dindiang kojo olah abi dindiang dek dawek pena, nyo tuluak aghi manuli tu kojo.

9. Dicampak-campaan towi kuciang ko, baliak lo liak ka umah lah abi ikan den dimakannyo.

10. Ado tako ughang kecelakaan di jalan, tahompe-hompe honda inyo de sampai ancugh kali.

11. Yo idak takuik mati nampak den da pajagh tu de, tuluak malam mabuak-mabuan nyia kojo.

Berdasarkan kalimat di atas, reduplikasi yang terjadi pada kata balaghilaghi, maingek-ingek, malompek-lompek, bajalan-jalan, bajomugh-jomugh, mangunyahngunyah, mancukigh-cukigh, manuli-nuli, dicampak-campaan, tahompe-hompe, dan 
mabuak-mabuan, menjelaskan bahwa berulang

kalinya dilakukan pekerjaan tersebut.

\section{Makna Menyatakan Sedang Berlangsung atau Dilakukan Terus-menurus}

1. Anak ughang tu dai tadi lai bagolak-golak jua nampak den.

2. Ancak nampak den gambar tu de, dai tadi den manengok-nengok lai tapi ndak jua pue den nengok da.

3. Olah malam kini ko, masih juo nyo mondagh-mandigh dopan umah de, poniang palo den nengoknyo.

4. Goghak-gaghik ughang tu dai tako den tengok ado yang aneh nampak den, ntah apo tujuannyo gak de.

5. Lambek-lambek nyia ga so poi motor koa, olah lamo aso ndak jua sampai-sampai da.

6. Jan laghi-laghi jua lai kojo, ndak nampak kau da ado tamu siko yia?.

7. Duduak-duduak jua kojo kau nampak den dai tako, tolonglah kakak kau tu basuah pinggan.

Reduplikasi bagolak-golak, bacokakcokak, mamasak-masak, dan mauang-muang, menjelaskan bahwa kata tersebut berulang kali dilakukan atau terus menerus.

\section{Menyatakan Makna berbalasan}

1. Katiko den lalu dokek pasagh, nampak den tukang parkir tampagh-manampagh kojonyo, ndak ado yang nak ngalah.

2. Den jopuik kawan den ka umahnyo, nyo jopuik lo e san den ka umah den, jopuikmanjopuik la kojo kami jadinyo.

3. Katiko den nyimoghang jalan jo anak den, pogang-mamogang tangan kami, takuik yo anak den banyak motor lojugh-lojugh.

4. Bacokak anak den jo anak kakak tu, piciak e anak den tu piciak lo dek anak den e ngkau, piciak-mamiciak bodua yo.

5. Tengok-tengokan nampak den jajagh tu de, saling suko sak ati den yo.

6. Aghi ayo tu de olah trasidisi awak untuak salam-salaman, apolagi samo keluarga dokek.

Reduplikasi tampagh manampagh terdapat pada kalimat 'katiko den lalu dokek pasagh, nampak den tukang parkir tampagh- manampagh kojonyo, ndak ado yang nak ngalah, menjelaskan bahwa tukang parkir yang sedang kelahi dan saling tampar-menampar satu sama lain. Jopuik-manjopuik dalam kalimat 'den jopuik kawan den ka umahnyo, nyo jopuik lo e san den ka umah den, jopuikmanjopuik la kojo kami jadinyo, mempunyai arti bahwa dua orang sahabat yang saling menjemput ke rumah masing-masing. Begitupula dengan reduplikasi yang lain menjelaskan bahwa mempunyai makna saling atau berbalasan.

\section{Menyatakan Makna Sampai atau Pernah}

1. Olah diangkek e ha kain nyo de, olah balama-malam nampak den jomugh e situ.

2. Pajagh tu olah baaghi-aghi nyo poi dai umah bau tako bau baliak yo, olah komak kingho omaknyo de.

'olah diangkek e ha kain nyo de, olah balama-malam nampak den jomugh e situ, menjelaskan bahwa seseorang pernah menjemur pakaiannya sampai bermalammalam.

\section{Makna Superlatif}

1. Saancak-ancak e muko ughang tapi kalau akhlak nyo buwuak indak juo suko ughang do, jadi jagolah sikap apolagi kalau awak padusi.

2. Olah jole nyo sagendut-gendut e masih juo nyo makan malam, indak bisa nyo mangontrol makan nyo da.

3. Ontah apo masalah gak oajagh tu, sampai sakuwi-kuwi e badan nyo. Jan kan bagaya basikek ajo jaghang.

4. Sapendek-pendek $e$ anak tu tapi inyo tia yang paliang copek wktu lomba bonang dulu.

5. Anak Kades tu ndak ado sombong saketek jua da, tapi saelok-elok nyo ugahng lai towi salah di mato ughang lain.

6. Ughang dopan umah den tu yo tia saketek eleok laku, sakayo-kayo $e$ indak tia ponah sombong samo den do.

'Saancak-ancak e muko ughang tapi kalau akhlak nyo buwuak indak juo suko ughang do, jadi jagolah sikap apolagi kalau awak padusi', reduplikasi Saancak-ancak $e$ 
dalam kalimat tersebut menjelaskan bahwa makna paling cantik. Begitu pula dengan makna yang lain menyatakan makna paling.

\section{Menyatakan Makna Demi}

1. Ilang tolugh ayam den yang di kandang tu, tuluak aghi sabutigh-butigh ilang yo. Musang gak nan makan ntah ulagh.

2. Ado acara wirid potang di umah, ndak tolok den mahidang sodonyo de sakalian nyo sakik tangan den, samangkuaksamangkuak nyia den angkek lu.

3. Sayuran yang den jual tu sakobek-kobek olah busuaknyo, untuang ayur bayam olun busuak lai.

'Ilang tolugh ayam den yang di kandang tu, tuluak aghi sabutigh-butigh ilang yo. Musang gak nan makan ntah ulagh', pada kalimat ini menjelaskan bahwa sebutir-demi sebutir telur ayamnya hilang. Pada kalimat 'ado acara wirid potang di umah, ndak tolok den mahidang sodonyo de sakalian nyo sakik tangan den, samangkuak-samangkuak nyia den angkek lu', menjelaskan bahwa hanya semangkuk demi semangkuk hidangan yang bisa diangkatnya. Begitupula pada kalimat (3) menjelaskan seikat demi seikat sayuran yang dijualnya membusuk.

\section{Menyatakan Makna Kolektif}

1. Bekko agin ka den pena tu kak tigo-tigo de mua, jan ado yang tinggagh.

Reduplikasi dalam kalimat 'bekko agin ka den pena tu kak tigo-tigo de mua, jan ado yang tinggagh', mempunyai makna bahwa ketiga-tiganya atau semua pena harus diberkan secara bersamaan.

\section{SIMPULAN}

Berdasarkan penelitian yang telah dilakukan mengenai reduplikasi bahasa Melayu Riau dialek Kampar Kiri dapat diperoleh simpulan bahwa penggunaan reduplikasi sangat banyak ditemukan dalam ujaran maasyarakat Kampar Kiri. Namun, mayoritas orang tua yang menggunakan bahasa tersebut.

Reduplikasi bahasa Melayu Riau dialek Kampar Kiri sering digunakan oleh masyarakat dalam percakapan, hal ini dikarenakan adanya satuan-satuan kata tertentu yang memang sudah terbentuk dan ditentukan, reduplikasi yang terdapat pada percakapan masyarakat Kampar Kiri hampir sama dengan reduplikasi yang ada pada percakapan bahasa Indonesia, hanya saja ada fonem-fonem tertentu yang membedakan tulisan dan pengucapannya.

Berdasarkan penelitian yang telah dilakukan penulis mengenai reduplikasi bahasa Melayu Riau dialek Kampar Kiri dapat diperoleh simpulan bahwa ada sepuluh bentuk reduplikasi yang terdapat pada bahasa Melayu riau dialek Kampar Kiri yaitu satu reduplikasi beinfiks, tiga reduplikasi bersimulfiks, enam reduplikasi berprefiks pada lingga pertama, empat reduplikasi berprefiks pada lingga kedua, dan tiga reduplikasi bersufiks. Selain itu, enam reduplikasi berkonfiks, lima reduplikasi dwilingga, tiga reduplikasi dwilingga salin suara, sepuluh reduplikasi dwipura berafiks, dan sepuluh reduplikasi dwipura tanpa afiks.

Makan reduplikasi yang telah didapatkan setelah melakukan penelitian di Kecamatan Kampar Kiri yaitu terdapat tiga makna bermacam-macam, dua menyatakan arti menyerupai atau seperti, sepuluh arti jamak, sebelas menyatakan bahwa pekerjaan yang dilakukan berkali-kali atau berulang-ulang, tujuh menyatakan bahwa pekerjaan yang disebutkan dalam kata dasarnya sedang berlangsung atau terus-menerus, enam makna berbalasan, dua makna sampai atau pernah, enam makna superlatif, tiga makna demi, dan hanya ditemukan satu makna kolektif. Makna yang tidak dinyatakan oleh Keraf dan didapatkan penulis dalam penelitian ini yaitu makna demi, makna yang menyatakan sedang berlangsung atau terus-menerus dilakukan, dan makna berkali-kali atau berulang-ulang. Jumlah keseluruhan data mengenai makna reduplikasi yang terdapat pada dialek Kecamatan Kampar Kiri Kabupaten Kampar berjumlah 51 data.

Penjelasan di atas merupakan data yang diperoleh peneliti di Kecamatan Kampar Kiri sesuai dengan teknik pengumpulan data melakukan wawancara di Kecamatan Kampar Kiri Kabupaten Kampar.

Reduplikasi Bahasa Melayu Riau Dialek Kampar Kiri 


\section{REFERENSI}

Alber, A., \& Febria, R. (2018). Analisis Kesalahan Berbahasa Tataran Sintaksis dalam Kumpulan Makalah Mahasiswa Universitas Islam Riau. GERAM, 6(2). https://doi.org/https://doi.org/10.25299/g eram.2018.vol6(2).2143

Asnawi. (2017). Afiks Pembentuk Reduplikasi Nominal Bahasa Banjar Hulu: Tinjauan Bentyk Gramatikal. GERAM (Gerakan Aktif Menulis), 5(1), 33-42. https://doi.org/10.1017/CBO9781107415 324.004

Auzar dan Hermandra. (2007). Sosiolinguistik. Pekanbaru: Cendikia Insani.

Charlina dan Mangatur Sinaga. (2007). Morfologi. Pekanbaru: Cendikia Insani.

Keraf, G. (1989). Tata Bahasa Indonesia. Jakarta: Nusa Indah.

Kridalaksana, H. (2008). Kamus Linguistik Edisi keempat. Jakarta: Gramedia Pustaka Utama.

Kurniawam, H. (2015). Gramatikalisasi dalam Petunjuk Perlatihan Buku Teks Bahasa Indonesia SMA Kelas X. Jurnal Pena Indonesia Jurnal Bahasa Dan Sastra Indonesia Serta Pengajarannya, 1(2), 42-58.

https://doi.org/http://dx.doi.org/10.26740/ jpi.v1n2.p163-195

Moleong, L. (2005). Metode Penelitian Kualitatif. Bandung: Remaja Rosdakarya.

Muslich, M. (2010). Tata Bentuk Bahasa Indonesia. Jakarta: Bumi Aksara.

Nalenan, J. S. (2019). Bentuk Bahasa Kasual Guyub Tutur di Wilayah Perumahan BTN Kefamenanu. JUBINDO, 4(1). Retrieved from http://jurnal.unimor.ac.id/JBI/article/view /202/196

Oktavia, W. (2018). Analisis Kesalahan Berbahasa Bidang Morfologi dalam Wacana Jual Beli Daring di Instagram. JALABAHASA, 14(1). https://doi.org/https://doi.org/10.36567/ja labahasa.v14i1.136

Ramlan. (2001). Morfologi Suatu Tinjauan Deskriptif. Yogyakarta: CV Karyono. 